\title{
Deemed Universities in India: Confusion Reigns
}

\section{Asha Gupta}

Asha Gupta, an affiliate with the University at Albany Program for Research on Private Higher Education, is currently at the Directorate of Hindi Medium Implementation, University of Delhi. E-mail: ashagupta3452@gmail.com.

IHE devotes a column in each issue to a contribution from PROPHE, the Program for Research on Private Higher Education, headquartered at the University at Albany. See http:/ / www.albany.edu/ .

Confusion prevails over the future of India's institutions confusingly titled "deemed to be universities." According to the University Grants Commission Act of 1956, the "deemed-to-be-a-university" status can be granted to any higher education institution other than a university, on the recommendation of the UGC, by the central government. These institutions enjoy more autonomy than regular universities in terms of fee structure, admissions process, curricula designing, and degrees to be awarded. They can be public or private and have enjoyed the status of universities without being established by national or state legislation.

On January 18, 2010, the government filed an affidavit in the Supreme Court proposing withdrawal of deemed-university status in the case of 44 private higher education institutions, spread over 13 states with an aggregate enrollment of 200,000 students. Soon after coming into power in May 2009, the 
Congress Party-led government had constituted a committee to look into several aberrations in the functioning of India's existing 132 deemed universities. The committee evaluated 127 deemed universities (41 government funded and 86 private) and came to the conclusion that only 38 were justified in retaining this status. It found 44 institutions deficient in terms of academic curriculum, research, governance, and infrastructure and gave them three years to improve their functioning. The committee recommended the scrapping of the deemed status in the rest of the 44 institutions. One deemed university did not turn up for the review.

Deemed universities were conceptualized by the UGC on the recommendations of the Radhakrishnan Committee set up in 1948. The idea was to grant university status to those institutions that for historical reasons or other circumstances could not become universities but were engaged in high-standard, specialized academic fields. From 1956 to 1999, the status of deemed university was conferred only on 37 institutions-such as, the prestigious Indian Institute of Science in Bangalore, the Indian Agricultural Research Institute in Delhi, the Tata Institute of Social Sciences in Mumbai, and the Birla Institute of Technology and Science in Pilani.

However, a new government in 1999 granted this status en bloc to 17 regional engineering colleges and several other private institutions providing professional courses, such as the Manipal Academy. From 1999 to 2009, their number rose from mere 37 to 127 . In 1999, a special provision was made to confer the status of de novo universities for institutions showing "potential for excellence" in terms of innovative teaching methods and research, rather than excellence per se. 


\section{From DEEMED to DOOMED UNIVERSITIES}

However, the criteria for awarding the status of deemed universities have been sharply watered down over the years. No longer do most institutions holding this title show high quality and innovative teaching and research. Instead, many of the private institutions are run by politicians and/or family fiefdoms under the guise of charitable trusts or societies established under the Indian Societies Registration Act of 1860. In fact, many reports in the media regarding the UGC Review Committee have turned a blind eye to academic and infrastructural deficiencies and taken decisions purely on an ad hoc basis.

The committee, established by the Human Resource Development Ministry, in its 2010 report finds few of the errant 44 deemed universities actually engaged in some serious or meaningful research. In most cases, it finds the institutions in question by admitting students far beyond their intake capacity and running many distance education programs without prior approval. Most have underqualified faculty and/or poor infrastructure. Some are found allegedly functioning on illegal land, while others are offering classes and laboratories at odd hours. The committee also finds the 132 deemed universities ignoring the guidelines from the UGC and other mandatory regulatory bodies, such as the Medical Council of India.

\section{NEED OF THE HOUR}

It is not surprising that Kapil Sibal, the new human resource development minister found it necessary to freeze the sanctioning of new deemed universities and place the existing deemed universities under the scrutiny of a high-powered 
committee. Even the 22-member Yashpal committee, in its report on "Renovation and Rejuvenation of Higher Education in India" in 2008, had recommended maintaining the deemed status until rational guidelines are evolved. The erstwhile United Progressive Alliance government has yet to pass legislation regulating the establishment and running of private and foreign higher education institutions in India. Four bills are pending before the Parliament, aiming at stopping the malpractices in private higher education and paving the way for foreign universities in India. The real test lies in providing an environment that fosters innovation but deters malpractices.

Given the lack of proper legislation, the existing state of uncertainty is reinforced by the Supreme Court's halting of the 44 deemed universities found in violation by the government. It has asked them to prove in the next three years their worth, based on the special status accorded to them. Meanwhile, the UGC has put a bar on running distance-learning programs by the deemed universities. Additionally, the All India Council for Technical Education has formulated new guidelines for allowing the corporate sector to establish private universities directly, instead of taking the guise of charitable trusts. In fact, in its true spirit, the concept of deemed universities can enhance both quality and employability in due course. It can encourage qualitative research and inclusive development necessary for the knowledge- and technology-driven modern economies. 